SAINS TANAH - Journal of Soil Science and Agroclimatology

Journal homepage: http://jurnal.uns.ac.id/tanah

\title{
Formulation of bacterial consortium for improvement growth and yield of maize (Zea mays L.)
}

\author{
Ali Ikhwan, Aniek Iriany*, Erny Ishartati, Faridlotul Hasanah \\ Department of Agrotechnology, Faculty of Agriculture, University of Muhammadiyah Malang, Indonesia
}

\begin{tabular}{|c|c|}
\hline ARTICLE INFO & ABSTRACT \\
\hline $\begin{array}{l}\text { Keywords: } \\
\text { Crop productivity } \\
\text { Maize } \\
\text { PGPB consortium } \\
\text { Article history } \\
\text { Submitted: 2020-08-12 } \\
\text { Accepted: 2021-06-26 } \\
\text { Available online: 2021-06-30 } \\
\text { Published regularly: June 2021 } \\
\text { * Corresponding Author } \\
\text { Email address: } \\
\text { aniek55@yahoo.co.id }\end{array}$ & $\begin{array}{l}\text { Plant growth-promoting bacteria (PGPB) have become an important subject of research to } \\
\text { increase maize production. The PGPB consortium should provide more benefits than single } \\
\text { or dual inoculation. This study aimed to investigate the effect of a PGPB consortium on } \\
\text { improving maize growth and yield. The field experiment used a split-plot design. The main } \\
\text { plot consisted of three maize varieties (Talenta, Pertiwi-3, and Bisma), and the subplot } \\
\text { consisted of three formulations of PGPB consortia [endophytic bacteria isolates, } \\
\text { Acetobacter sp., cellulolytic, and ligninolytic (F1); endophytic bacteria isolates, Azospirillum } \\
\text { sp., cellulolytic, and ligninolytic (F2); and endophytic bacteria isolates, cellulolytic, } \\
\text { ligninolytic, Acetobacter sp., and Azospirillum sp. (F3)] and one control. PGPB consortia } \\
\text { formulation did not influence maize growth significantly, but maize varieties did. Pertiwi-3 } \\
\text { showed the highest value in all growth variables, followed by Bisma and Talenta, } \\
\text { respectively. The effect of PGPB consortia formulation upon ear fresh and dry weight } \\
\text { depends upon the maize variety, and Pertiwi-3 showed the highest value in yield variables. } \\
\text { PGPB consortia formulation } 2 \text { was the most effective to apply for Pertiwi-3 cultivation, } \\
\text { while PGPB consortia formulation } 3 \text { produced higher yields for Talenta and Bisma. These } \\
\text { findings indicated that specific PGPB formula could improve the yield for specific maize } \\
\text { varieties. }\end{array}$ \\
\hline
\end{tabular}

How to Cite: Ikhwan, A., Iriany, A., Ishartati, E., Hasanah, F. (2021). Formulation of bacterial consortium for improvement growth and yield of maize (Zea mays L.) [Research]. Sains Tanah Journal of Soil Science and Agroclimatology, 18(1): 89-97. https://dx.doi.org/10.20961/stjssa.v18i1.46003

\section{Introduction}

Maize (Zea mays L.) is an important crop not only consumed as a staple food (30\%) but also as feed (65\%) and raw materials (5\%) (Panikkai et al., 2017). Approximately 12,500 million tons (Mt) of maize were consumed in Indonesia in 2017/2018. However, national maize production in that year only generated $11,900 \mathrm{Mt}$. Approximately $0.6 \mathrm{Mt}$ were imported to make up for the shortfall (Mcdonald \& Meylinah, 2019). Compared to top maize producers in the world e.g., USA and China, Indonesian maize productivity (tons ha-1) lagged behind, with 5.3 compared to 11.1 of the US, 6.1 of China, and 5.7 of global maize production. Several efforts to increase maize production involved extensification, which increased 1.4\% of the harvest area in 2018-2019 (Mcdonald \& Meylinah, 2019). However, any extensification efforts must be accompanied by intensification because the total of arable land available for cultivation is limited; some of them are being rapidly converted to non-agricultural use ( $\mathrm{Li}$ et al., 2019). Currently, agricultural intensification is taking an interest in environmentally sustainable approaches. This perspective modifies the agroecosystem to minimize the negative impact of synthetic input (fertilizer, pesticide, etc.) and maintain economic profitability with on-farm resources, such as native beneficial microbiota, to promote plant growth and increase yield (Pérez-Montaño et al., 2014; Velten et al., 2015).

Plant growth-promoting bacteria (PGPB) has become an important subject of research to increase maize productivity (Di Salvo et al., 2018). PGPB can fertilize soils and promote plant growth when applied as a biofertilizer (Olanrewaju \& Babalola, 2019) through several mechanisms, including phytohormone production, nutrient release, and biotic/abiotic stress alleviation (Santos et al., 2019). Those properties increased yield and boosted crop production, aligning with the intensification goal (Fukami et al., 2016). Particularly in maize, PGPB inoculation has been demonstrated promising, e.g., it improved agronomic 
performance, increased yield, and reduced susceptibility to biotic/abiotic stress (Fitriatin et al., 2017; Olanrewaju \& Babalola, 2019; Ullah et al., 2020).

In biofertilizer formulation, it is possible to mix and combine several PGPB strains in a consortium to apply in the field. This idea comes from the fact that many bacteria could live together and establish a mutualistic relationship (Olanrewaju \& Babalola, 2019). Furthermore, not all PGPB are capable of exerting the same mechanism. Some excel in fixing nitrogen, while others may be proficient at producing phytohormone, etc. Hence, by combining PGPB in a consortium, more benefits can be provided (Malusà et al., 2016). The superiority of consortium compared to single or dual inoculation was reported in several papers. For example, Akhtar et al. (2018) reported better maize performance with bacterial consortium than single or dual inoculation in Fusarium infested soils. Irfan et al. (2019) found the same benefit in a saline environment. This may occur because the consortia convert multiple nutrients, enhance microbial activity in the soil, and convert nutrients through the symbiotic association of bacteria and plant roots. This, in turn, promotes nodulation, nitrogen and phosphorus cycling, promotion in plant growth, increased grain yield, and protein concentration (Moretti et al., 2020).

This study investigated the effect of inoculating a PGPB consortium on maize performance and yield. The consortium comprises isolates of endophytic, cellulolytic, ligninolytic bacteria, Acetobacter sp. and Azospirillum sp. Studies on PGPB consortia to apply in maize are still rare. Therefore, this paper may be a reference for future studies on using PGPB consortia as a biofertilizer to improve maize production in Indonesia. This study aimed to investigate the effect of a PGPB consortium on improving the growth and yield of several maize varieties.

\section{Materials and Method}

\subsection{Preparation of PGPB consortia formulation}

PGPB consortia used in this study were composed of unidentified endophytic isolates (JC2A, JC4D, JC5B, JC5D, JC5T, JH3A, JMH3B, and JMH3T), unidentified cellulolytic, ligninolytic, Acetobacter sp., and Azospirillum sp. These isolates were prepared and obtained by Kurniawan (2016).
Before use, all isolates were mixed, grown in M63 medium, and harvested in a large-scale fermentor as described by Kurniawan (2016).

\subsection{Experimental design}

Laboratory work was carried out in the Department of Agrotechnology's laboratory, University of Muhammadiyah Malang. Meanwhile, a field study was conducted in Karangploso, Malang, Indonesia (-7.9175924 ' $\mathrm{S}$, $112.6142577^{\circ} \mathrm{E}$ ) with an altitude of $550 \mathrm{~m}$, daily temperature range of $25-32{ }^{\circ} \mathrm{C}$, and rainfall $3600 \mathrm{~mm}$ year ${ }^{-1}$. The field experiment was carried out using a split-plot design with twelve treatment combinations and three replications. The main plot was three maize varieties i.e. Talenta, Pertiwi-3, and Bisma. The subplot was PGPB consortia formulation, arranged in four combinations: $F O$ (control without inoculation), F1 (5 $\mathrm{ml}$ of each JC2A, JC4D, JMH3B, JMH3T, Acetobacter sp., cellulolytic, and ligninolytic), F2 ( $5 \mathrm{ml}$ of each JMH3T, JC5B, JC5D, JC5T, Azospirillum sp., cellulolytic, and ligninolytic), and F3 (5 ml of each JH3A, JC5D, JMH3B, JC5T, cellulolytic, and ligninolytic; and $2.5 \mathrm{ml}$ of each Acetobacter sp. and Azospirillum sp.). PGPB consortia formulation was applied through soil drenching three times: sowing day, 14, and 28 days after sowing, with a dose of $200 \mathrm{ml} \mathrm{plant}^{-1}$ in each application.

\subsection{Measured variables}

Variables measured included plant growth and yield parameters. They are plant height, number of leaves, leaf area, fresh root weight, plant biomass, fresh ear weight, ear dry weight, cob weight, and 100 seed weight. Plant height, number of leaves, and leaf area were measured during weeks 2-7 (tasseling period). Fresh root weight and plant biomass were measured by weighing the lower and upper parts of plants (soil level as the reference) once at the end of the observation. Fresh and dry ear weights were collected before and after the water content was removed by sun-drying. Cob weight was determined by weighing the dry maize ear without husk, and 100 seeds weight were obtained by weighed on water content $14 \%-15 \%(w / w)$.

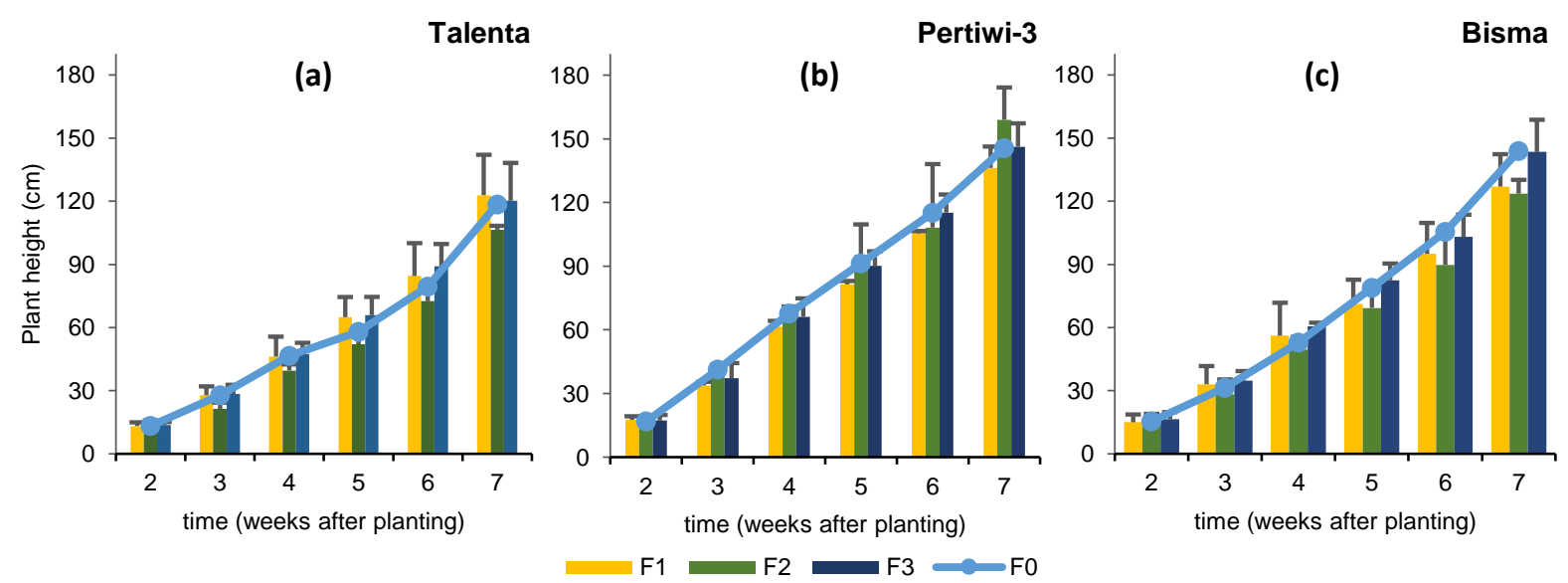

Figure 1. Plant height of three maize varieties under various endophytic bacteria formulations at 2 until 7 weeks after planting (Note: F0 = control, F1 = Plant growth-promoting bacteria (PGPB) consortia formulation 1, F2 = endophytic bacteria formulation 2, F3 = PGPB consortia formulation 3; bars represent standard deviation) 
Table 1. Growth of maize under Plant Growth-Promoting Bacteria (PGPB) consortia formulations and three maize varieties at the end of the observation

\begin{tabular}{|c|c|c|c|c|c|}
\hline Treatments & Plant height $(\mathrm{cm})$ & $\begin{array}{c}\text { Number of } \\
\text { leaves }\end{array}$ & Leaf area $\left(\mathrm{cm}^{2}\right)$ & $\begin{array}{l}\text { Root fresh weight } \\
\text { (g) }\end{array}$ & Plant biomass (g) \\
\hline \multicolumn{6}{|c|}{ PGPB consortia formulations } \\
\hline FO & $163.84 \mathrm{a}$ & $12.92 \mathrm{a}$ & $481.32 \mathrm{a}$ & $38.72 \mathrm{a}$ & $214.75 \mathrm{a}$ \\
\hline $\mathrm{F} 1$ & $152.35 \mathrm{a}$ & $12.67 \mathrm{a}$ & 470.42 a & $46.22 \mathrm{a}$ & $207.06 \mathrm{a}$ \\
\hline $\mathrm{F} 2$ & $151.17 \mathrm{a}$ & $12.94 \mathrm{a}$ & 493.93 a & $39.81 \mathrm{a}$ & $225.25 a$ \\
\hline F3 & $169.01 \mathrm{a}$ & $13.42 \mathrm{a}$ & $507.86 \mathrm{a}$ & $43.14 \mathrm{a}$ & $232.31 \mathrm{a}$ \\
\hline \multicolumn{6}{|l|}{ Maize varieties } \\
\hline Talenta & $131.92 b$ & $11.67 \mathrm{c}$ & $445.87 \mathrm{~b}$ & $20.83 c$ & $129.25 \mathrm{c}$ \\
\hline Pertiwi-3 & $177.67 \mathrm{a}$ & $14.19 \mathrm{a}$ & $525.77 \mathrm{a}$ & $60.71 \mathrm{a}$ & $319.69 \mathrm{a}$ \\
\hline Bisma & $167.68 \mathrm{a}$ & $13.10 \mathrm{~b}$ & $493.50 \mathrm{ab}$ & $44.38 \mathrm{~b}$ & $210.58 b$ \\
\hline
\end{tabular}

Remarks: Mean followed by the same letter in the same column showed no significant difference based on Tukey's HSD test $(\alpha=0.05)$; F0 = control, F1 = PGPB consortia formulation 1, F2 = PGPB consortia formulation 2, F3 = PGPB consortia formulation 3 .

\subsection{Statistical and data analysis}

The data were analyzed using analysis of variance to determine the effect of the treatments. The differences were assessed using Tukey's HSD test ( $\alpha$ 5\%) to find out the best treatment for any significant values. An interaction plot was used to understand the behavior of one variable depending on the other variables, while the main plot clarified the behavior of each factor level of a certain factor.

\section{Results}

\subsection{Effect of PGPB consortia formulation on growth parameters of three maize varieties}

During the observation time, maize plant height was not significantly different under different PGPB consortia formulations $(P>0.05)$. However, F3 tends to show higher plant height than F1 and F2 on Talenta dan Bisma, while on Pertiwi-3, F2 tends to show better plant height with the order was F2, F3, and F1, from highest to lowest respectively. A significant difference occurred among maize varieties (Figure 1).
Pertiwi and Bisma varieties showed significantly higher plant height (21-26\%) than Talenta during observation time $(P<$ 0.05) (Table 1).

The number of maize leaves did not show a significant difference under the application of various PGPB consortia formulations $(P>0.05)$. However, $\mathrm{F} 3$ treatment tends to show more leaves than other formulations. A significant difference occurred among maize varieties (Figure 2). Pertiwi-3 and Bisma had significantly more leaves than Talenta during the observation period $(P<0.05)$, with the order from the most to least number of leaves was Pertiwi-3, Bisma, dan Talenta (Table 1).

The difference of leaf maize area under the application of various PGPB consortia formulations was not visible during the observation period. However, each formula tends to exhibit better leaf area in a specific variety e.g., F1 in Talenta, F2 in Pertiwi-3, and F3 in Bisma (Figure 3). Pertiwi-3 showed a wider leaf area (6-15\%) than Bisma and Talenta. In addition, Pertiwi-3 produced a significantly wider leaf area (15\%) than Talenta (Table 1).

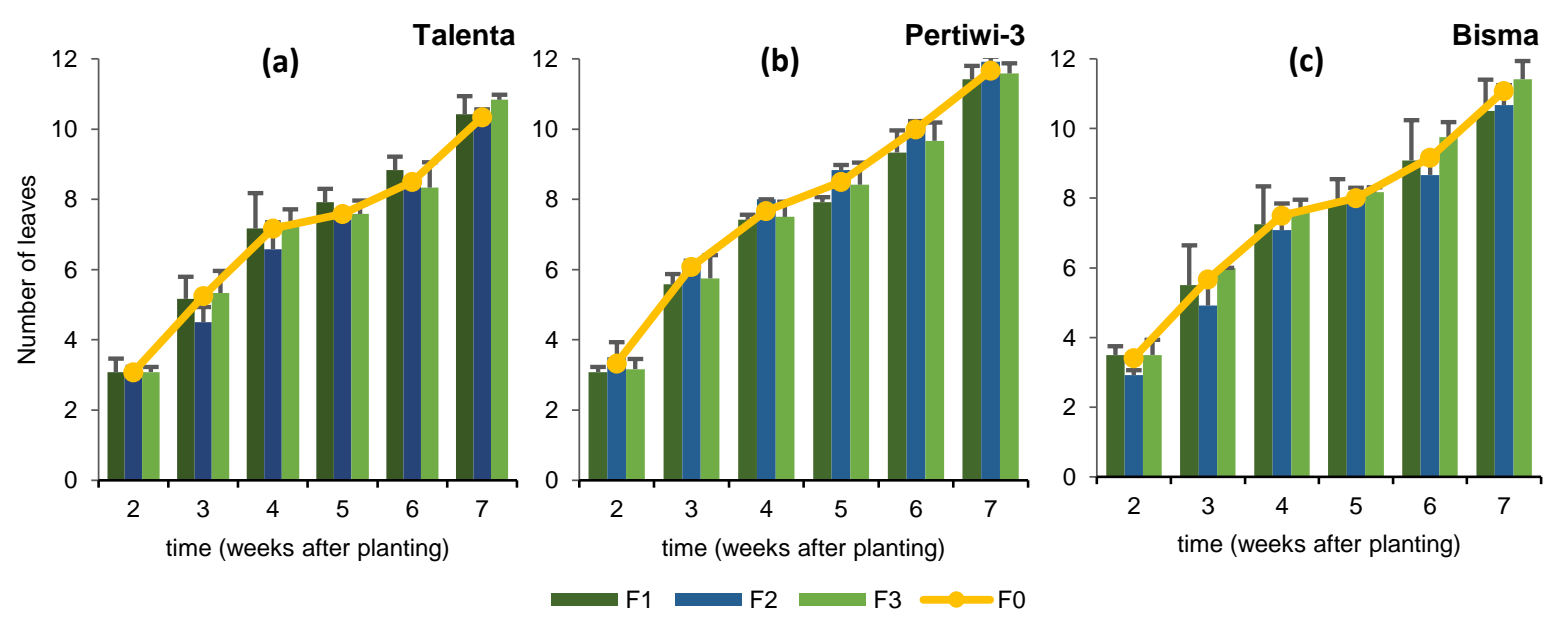

Figure 2. Number of maize leaves under various Plant growth-promoting bacteria (PGPB) consortia formulations on three maize varieties at 2 until 7 weeks after planting (Note: F0 = control, F1 = PGPB consortia formulation 1, F2 = PGPB consortia formulation 2, F3 = PGPB consortia formulation 3; bars represent standard deviation) 


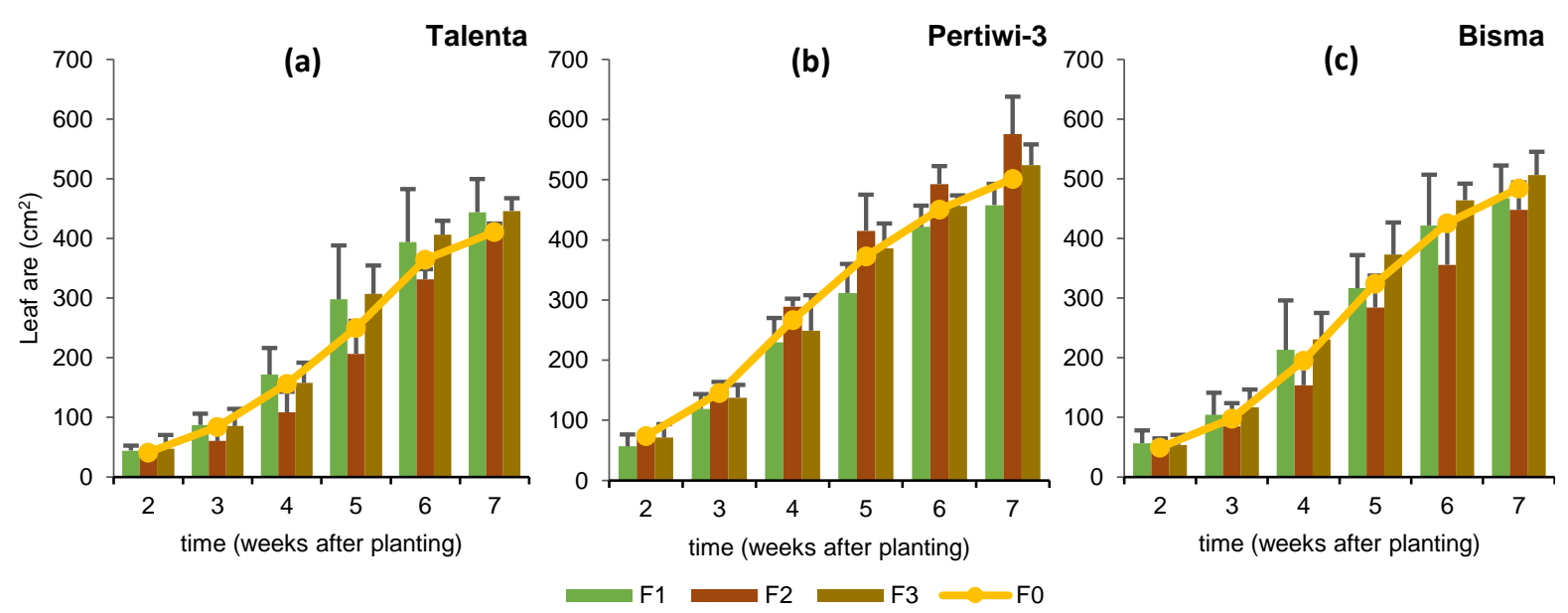

Figure 3. Leaf area of three maize varieties under various Plant growth-promoting bacteria (PGPB) consortia formulations at 2 until 7 weeks after planting (Note: F0 = control, F1 = PGPB consortia formulation 1, F2 = PGPB consortia formulation 2, F3 = PGPB consortia formulation 3; bars represent standard deviation)

(a)
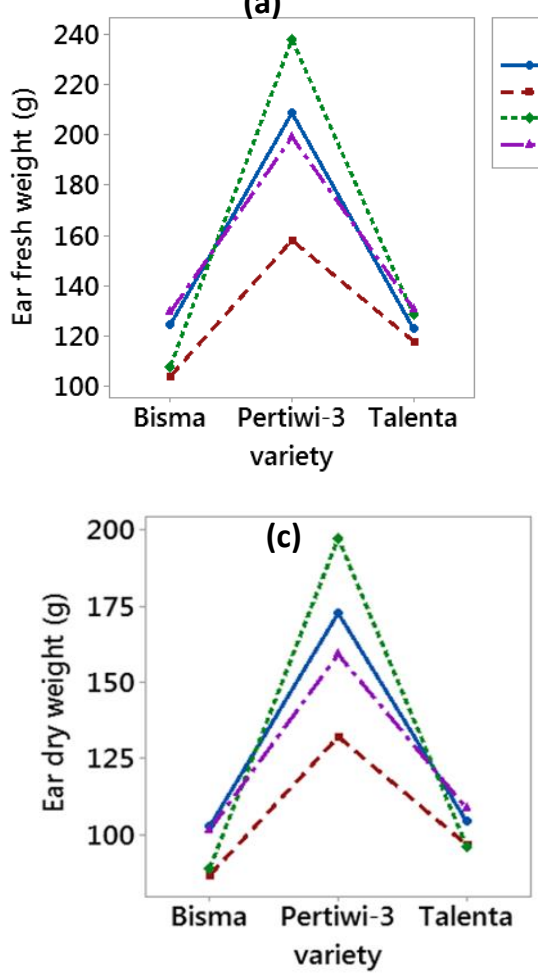

(b)
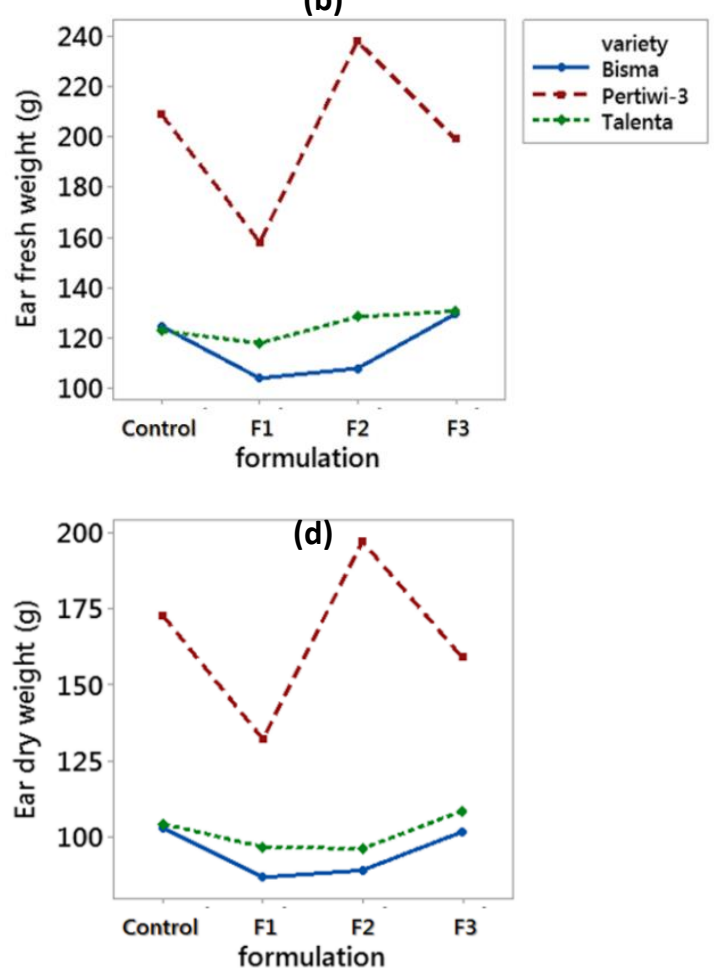

Figure 4. Interaction plot for fresh ear weight ( $a$ and $b$ ) and dry ear weight (c and $d$ ) of three maize varieties under various Plant growth-promoting bacteria (PGPB) consortia formulation

Fresh root weight and plant biomass did not show a significant difference in all PGPB consortia formulations at the end of observation, but F1 tends to show heavier fresh root weight than F3 and F2. F3 tends to exhibit higher plant biomass than F2 and F1. Pertiwi-3 demonstrated significantly heavier fresh root weight (27-66\%) and plant biomass (34$60 \%)$ than Bisma and Talenta at the end of observation $(P<$ 0.05) (Table 1).

\subsection{Effect of PGPB consortia formulation on yield parameters of three maize varieties}

Table 2 shows the influence of the PGPB consortium application on yield variables of three maize varieties. Pertiwi-3 showed the heaviest fresh ear weight and dry ear weight of about $40 \%$ higher than other varieties in all PGPB consortia formulations. The order from the heaviest to the lightest was F2, F3, and F1 (Figure 4). Overall, the significant difference of fresh and dry ear weight between Talenta and Bisma did not appear in all those formulations (Table 2), but the highest mean value of ear fresh and dry weight of both varieties produced by F3 (Figure 4). The interaction plot of three maize varieties under various PGPB consortia formulation for ear fresh and dry weight variables (Figure 4) shows apparent interaction. Application of various PGPB consortia formulations did not show a significant difference in the cob weight or 100 seed weight variables $(P>0.05)$, but there was a significant difference due to maize varieties (Table 2). 
(a)

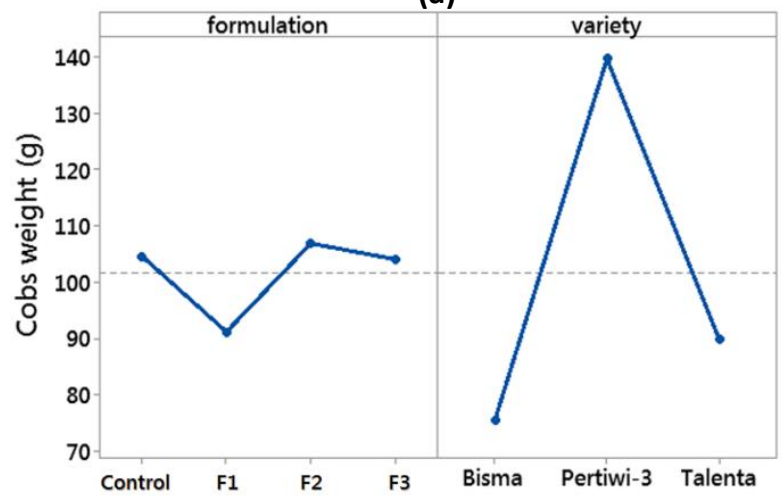

(b)

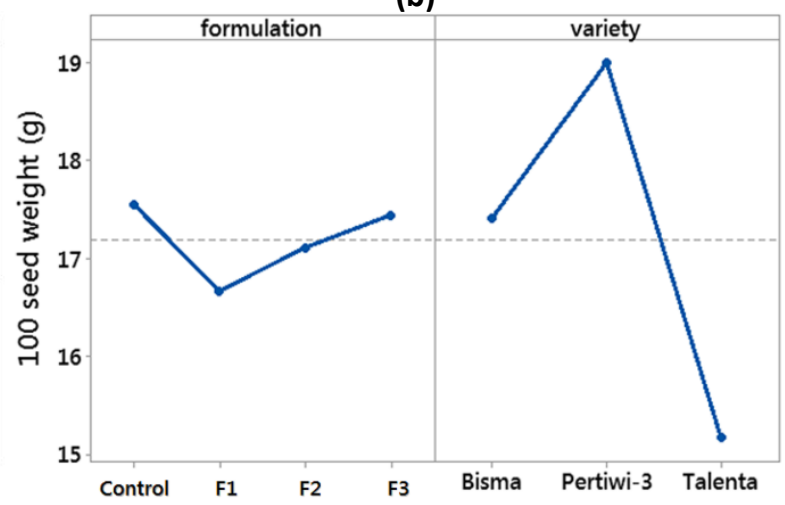

Figure 5. Main effects plot for cobs weight and 100 seed weight of three maize varieties under various Plant growth-promoting bacteria (PGPB) consortia formulation (Note: dash line represents the reference line of the response)

The highest cob weight appeared on the application of the F2 formula, followed by F3 and F1 treatments. In contrast, the highest 100 seed weight was seen on the application of the F3 formula, followed by F2 and F1, respectively. Furthermore, Pertiwi-3 produced significantly heavier cobs weight and 100 seed weight than Talenta and Bisma. The maize varieties' effects upon cob weight and 100 seed weight are larger than the PGPB consortia formulation's effects (Figure 5).

\section{Discussion}

The F2 and F3 treatments were the suitable PGPB consortia formulation for improving the growth of several maize varieties (Table 1 ), but the most effective PGPB consortia formulation to obtain better yield was depend on the maize variety (Table 2). The F2 treatment was the best PGPB consortia formulation to be applied for Pertiwi-3 cultivation, while the $\mathrm{F} 3$ treatment produced better yields for Talenta and Bisma (Figure 4). It can be explained by the composition of the PGPB consortia formula, either the interaction of bacteria strain or the presence of other nonsymbiotic bacteria. The F3 treatment consists of four strains of endophytic bacteria isolates (JH3A, JC5D, JMH3B, JC5T), combined with cellulolytic bacteria, ligninolytic bacteria, Azospirillum sp, and Acetobacter sp. The F3 formulation consists of four strains of endophytic bacteria isolates (JMH3T, JC5B, JC5D, JC5T), without Acetobacter sp. The previous studies reported that bacteria isolated from maize rhizosphere in several countries, including Indonesia, were classified to genera Bacillus sp., Pseudomonas sp., Serratia sp, Agrobacterium sp., Azospirillum sp., Acetobacter sp, Achromobacter sp., and Stenotrophomonas sp. (Abiala et al., 2015; Agbodjato et al., 2015; Arsita et al., 2020; Sondang et al., 2019; Tchakounté et al., 2018; Wen et al., 2016; Youseif, 2018). Those bacteria directly promote plant growth by producing phytohormones (Jambhulkar et al., 2016) and enhance the stress tolerance of plants (Sirari et al., 2016). Various benefits of bacteria isolated from maize rhizosphere, e.g., genera Stenotrophomonas sp., Agrobacterium sp., and Achromobacter sp. as mentioned before, proved to contribute to nutrient availability. Azospirillum sp. is a nonsymbiotic bacteria, characterized as a free-living N2-fixer. It plays a role in phosphate solubilization and gibberellic acid production (Pérez-Montaño et al., 2014; Richard et al., 2018; Zayed, 2016). Acetobacter sp. produced indole acetic acetic
(IAA) in free environment conditions and increased root length, fresh root weight, and protein content in palm oil seedlings (Purwanto et al., 2019).

Based on this study, varieties strongly influence maize growth. Pertiwi-3 showed the highest value in all growth variables, followed by Bisma and Talenta, respectively (Table $1)$. The trend of these results in accordance with research reported by Pesireron \& Senewe (2011) and Zulfahmi et al. (2013). The PGPB consortia formulation did not significantly influence the growth of maize. A study by Lin et al. (2018) indicated that several PGPR formulations consisting of 4 strain bacteria classified as Pseudomonas sp. and Bacillus sp., did not significantly affect the growth of maize at V4, V6, and VT growth stages. PGPR treatment on maize seeds also did not significantly affect the growth parameters of maize under field conditions (Nezarat \& Gholami, 2009). Although there was no significant difference between formulations in this study, F1 tend to exhibit inferior maize growth, except for fresh root weight variable, compared to non-inoculated control, while F2 and F3 showed better growth than noninoculated control (Table 1). It can be caused by the interrelation between each isolate or bacteria inoculant. In general, various studies reported on better plant growth with bacteria inoculation, such as Azospirillum sp., Acetobacter sp., and other symbiotic or non-symbiotic bacteria, especially root growth variables (Jhala et al., 2016). Cassán et al. (2009) suggest photostimulation as a role of genera Azospirillum, Achromobacter, Burkholderia, and Arthrobacter. These strains have positive effects on root weight and nutrient uptake of maize plants, which might be attributable to phytohormone production and nutrient solubilization (PérezMontaño et al., 2014). Sirari et al. (2016) assert that hormones (IAA, gibberellin, and others) produced by PGPR increases root length, root tips, and root surface area. Youseif (2018) added that maize plants inoculated with Agrobacterium sp., one of the bacteria reported present in maize rhizosphere, showed significantly higher root length and fresh and dry weight of plant roots compared to uninoculated controls. It explained the heavier fresh root weight on inoculated (F1) than non-inoculated (control) one, although all growth variables showed inversely.

In summary, PGPB application, i.e., Acetobacter sp., Azospirillum sp. and other bacteria inoculated from the maize rhizosphere improved plant growth (Arsita et al., 2020; Curá 
et al., 2017; Di Salvo et al., 2018; Olanrewaju \& Babalola, 2019). A strong increase in total plant biomass of maize was obtained with inoculations of Burkholderia cepacia, Azospirillum brasilense, and Herbaspirillum seropedicae in individual experiments, in comparison with non $\mathrm{N}$ fertilize soil (Pérez-Montaño et al., 2014). In the broader range, Mehta et al. (2016) reported enhanced nitrogen availability after application of various strains of Azotobacter, Azospirillum, Phosphobacter, and Rhizobacter, increased plant height, the number of leaves, and stem diameters of Helianthus annuus. These results describe the role of PGPB to enhance nutrient use efficiency of fertilizer, solubilization, and mineralization of soil phosphorus (inorganic and organic), and its ability as free-living nitrogen-fixing PGPR so that nutrients became bioavailable. Nutrient absorption, especially $\mathrm{N}$ accumulation in plants, helps increase overall plant growth (Kumar et al., 2016; Mehta et al., 2016; Pérez-Montaño et al., 2014).

In terms of yield, Pertiwi-3 showed the highest value in yield variables (Table 2), which is consistent with studies reported by Pesireron \& Senewe (2011), Maryamah et al. (2017), and Prasetyo et al. (2018). It is supported by the main effects plot shown in Figure 5. The main effects plot displays the response means for each factor level in sorted order. The effects are the differences between the means and the reference line (Shah \& Freedman, 2011). Pertiwi-3 showed a higher means value than the reference line in yield variables (cobs weight and 100 seed weight).

Interaction between maize varieties and PGPB consortia formulation is present when the response at maize varieties depends upon the PGPB consortia or vice versa. The greater the difference between the lines from the parallel state, the higher level of interaction (Shah \& Freedman, 2011). Figure 4 shows a greater difference between varieties in the same PGPB consortia formulation than in the same varieties. It implies that PGPB consortium formulation's effect upon fresh and dry ear weight depends upon the maize variety. Previous work reported that the application of PGPR did not significantly affect growth parameters of maize under field conditions but did significantly affect several yield variables (Nezarat \& Gholami, 2009). Bacteria inoculation, e.g., Azospirillum sp. and its consortia, affected maize yield (increased up to 14\% dry weight) (Cassán et al., 2009; PérezMontaño et al., 2014).

Table 2. Yield observation of three maize varieties under application of Plant growth-promoting bacteria (PGPB) consortia formulation

\begin{tabular}{|c|c|c|c|c|}
\hline Treatment & Ear fresh weight $(\mathrm{g})$ & Ear dry weight (g) & Cobs weight (g) & 100 seed weight $(\mathrm{g})$ \\
\hline \multicolumn{5}{|l|}{ Control } \\
\hline Talenta & $122.58 \mathrm{~cd}$ & 104.17 c & & \\
\hline Pertiwi-3 & $208.75 a b$ & $172.75 a b$ & & \\
\hline Bisma & $124.33 \mathrm{~cd}$ & $102.67 \mathrm{c}$ & & \\
\hline \multicolumn{5}{|l|}{ PGPB consortium formula 1} \\
\hline Talenta & $117.67 \mathrm{~cd}$ & $96.50 \mathrm{c}$ & & \\
\hline Pertiwi-3 & $157.92 \mathrm{bc}$ & $132.08 \mathrm{bc}$ & & \\
\hline Bisma & $103.67 \mathrm{~d}$ & $86.50 \mathrm{c}$ & & \\
\hline \multicolumn{5}{|l|}{ PGPB consortium formula 2} \\
\hline Talenta & $128.17 \mathrm{~cd}$ & $96.00 \mathrm{c}$ & & \\
\hline Pertiwi-3 & 238.17 a & $197.42 \mathrm{a}$ & & \\
\hline Bisma & $107.58 \mathrm{~cd}$ & $88.83 \mathrm{c}$ & & \\
\hline \multicolumn{5}{|l|}{ PGPB consortium formula 3} \\
\hline Talenta & $130.50 \mathrm{~cd}$ & 108.42 c & & \\
\hline Pertiwi-3 & $199.17 \mathrm{ab}$ & $159.17 \mathrm{ab}$ & & \\
\hline Bisma & $129.25 \mathrm{~cd}$ & $101.50 \mathrm{c}$ & & \\
\hline Formulation x Maize varieties & $*$ & $*$ & ns & ns \\
\hline \multicolumn{5}{|l|}{ PGPB consortium formulation } \\
\hline F0 & & & $104.61 \mathrm{a}$ & $17.56 \mathrm{a}$ \\
\hline $\mathrm{F} 1$ & & & 91.17 a & $16.67 \mathrm{a}$ \\
\hline $\mathrm{F} 2$ & & & $106.89 \mathrm{a}$ & $17.11 \mathrm{a}$ \\
\hline F3 & & & $104.06 \mathrm{a}$ & $17.44 \mathrm{a}$ \\
\hline Formulation & & & ns & ns \\
\hline \multicolumn{5}{|l|}{ Maize varieties } \\
\hline Talenta & & & $89.90 \mathrm{~b}$ & $15.17 b$ \\
\hline Pertiwi-3 & & & $139.73 \mathrm{a}$ & $19.00 \mathrm{a}$ \\
\hline Bisma & & & $75.42 \mathrm{~b}$ & $17.42 \mathrm{ab}$ \\
\hline Maize varieties & & & $* *$ & $*$ \\
\hline
\end{tabular}

Remarks: Mean followed by the same letter in the same column showed no significant difference based on Tukey's HSD test $(\alpha=0.05)$; F0 = control, F1 = PGPB consortia formulation 1, F2 = PGPB consortia formulation 2, F3 = PGPB consortia formulation 3. 
Microbial consortia increased yield variables of the crop compared to single inoculant treatments (Olanrewaju \& Babalola, 2019). PGPR promotes it as phytostimulation, biofertilization $(\mathrm{N})$, and biocontrol (several root pathogens) (Cassán et al., 2009). Bacteria inoculation also reported had a positive response in other crops, i.e., wheat and Helianthus annuus, which resulted in a significant increase $\mathrm{N}$ accumulation in wheat grain, seed filling, and seed dry weight (Gopalakrishnan et al., 2016; Kumar et al., 2016; Mehta et al., 2016).

In brief, the results confirmed an improvement aspect of growth and yield of three maize varieties by application of PGPB consortia formulation. It was also presented as information regarding the best PGPB consortia formulation for each maize variety. However, characterization and identification of PGPB consortia at a molecular level and their role should be considered to understand the enhancement of growth and yield mechanism clearly.

\section{Conclusion}

PGPB consortia formulation did not influence maize growth significantly, but maize varieties did. Pertiwi-3 showed the highest value in all growth variables, followed by Bisma and Talenta, respectively. The effect of PGPB consortia formulation upon ear fresh and dry weight depends upon the maize variety, and Pertiwi-3 showed the highest value in yield variables. PGPB consortia formulation 2 was the most effective formulation for Pertiwi-3 cultivation, while PGPB consortia formulation 3 produced higher yields for Talenta and Bisma.

\section{Declaration of Competing Interest}

The authors declare no competing financial or personal interests that may appear and influence the work reported in this paper.

\section{References}

Abiala, M. A., Odebode, A. C., Hsu, S. F., Blackwood, C. B., \& Voordouw, G. (2015). Phytobeneficial Properties of Bacteria Isolated from the Rhizosphere of Maize in Southwestern Nigerian Soils. Applied and Environmental Microbiology, 81(14), 4736-4743. https://doi.org/10.1128/AEM.00570-15

Agbodjato, N. A., Noumavo, P. A., Baba-Moussa, F., Salami, H. A., Sina, H., Sèzan, A., Bankolé, H., Adjanohoun, A., \& Baba-Moussa, L. (2015). Characterization of Potential Plant Growth Promoting Rhizobacteria Isolated from Maize (Zea mays L.) in Central and Northern Benin (West Africa). Applied and Environmental Soil Science, 2015, 901656. https://doi.org/10.1155/2015/901656

Akhtar, N., Naveed, M., Khalid, M., Ahmad, N., Rizwan, M., \& Siddique, S. (2018). Effect of bacterial consortia on growth and yield of maize grown in Fusarium infested soil. Soil \& Environment, 37(1). https://doi.org/10.25252/SE/18/872

Arsita, R., Karim, H., Hala, Y., Iriany, N., \& Jumadi, O. (2020). Isolation and identification of nitrogen-fixing bacteria in the corn rhizosphere (Zea mays L.) originating from
Jeneponto Regency, South Sulawesi. IOP Conference Series: Earth and Environmental Science,

Cassán, F., Perrig, D., Sgroy, V., Masciarelli, O., Penna, C., \& Luna, V. (2009). Azospirillum brasilense Az39 and Bradyrhizobium japonicum E109, inoculated singly or in combination, promote seed germination and early seedling growth in corn (Zea mays L.) and soybean (Glycine max L.). European Journal of Soil Biology, 45(1),

28-35. https://doi.org/https://doi.org/10.1016/j.ejsobi.2008. 08.005

Curá, J. A., Franz, D. R., Filosofía, J. E., Balestrasse, K. B., \& Burgueño, L. E. (2017). Inoculation with Azospirillum sp. and Herbaspirillum sp. Bacteria Increases the Tolerance of Maize to Drought Stress. Microorganisms, 5(3), 41. https://www.mdpi.com/2076-2607/5/3/41

Di Salvo, L. P., Cellucci, G. C., Carlino, M. E., \& García de Salamone, I. E. (2018). Plant growth-promoting rhizobacteria inoculation and nitrogen fertilization increase maize (Zea mays L.) grain yield and modified rhizosphere microbial communities. Applied Soil Ecology, 126, 113-120. https://doi.org/https://doi.org/10.1016/j.apsoil.2018. 02.010

Fitriatin, B. N., Suryatmana, P., Yuniarti, A., \& Istifadah, N. (2017). The Application of Phosphate Solubilizing Microbes Biofertilizer to Increase Soil P and Yield of Maize on Ultisols Jatinangor. KnE Life Sciences, 2(6). https://doi.org/10.18502/kls.v2i6.1037

Fukami, J., Nogueira, M. A., Araujo, R. S., \& Hungria, M. (2016). Accessing inoculation methods of maize and wheat with Azospirillum brasilense. AMB Express, 6(1), 3. https://doi.org/10.1186/s13568-015-0171-y

Gopalakrishnan, S., Sathya, A., Vijayabharathi, R., \& Srinivas, V. (2016). Formulations of plant growth-promoting microbes for field applications. In Microbial Inoculants in Sustainable Agricultural Productivity (pp. 239-251). Springer.

Irfan, M., Zahir, A., Asghar, H. N., Khan, M. Y., Ahmad, H. T., \& Ali, Q. (2019). Effect of multi-strain bacterial inoculation with different carriers on growth and yield of maize under saline conditions. Int. J. Agric. Biol, 22, 1407-1414.

http://www.fspublishers.org/Issue.php?no_downloa d=published_papers/1577440906_21\%20doi\%2015.1 215\%20IJAB-18-1225\%20(8)\%2014071414.pdf\&issue_id $=40981$

Jambhulkar, P. P., Sharma, P., \& Yadav, R. (2016). Delivery systems for introduction of microbial inoculants in the field. In Microbial inoculants in sustainable agricultural productivity (pp. 199-218). Springer.

Jhala, Y., Shelat, H., \& Panpatte, D. (2016). Efficacy Testing of Acetobacter and Azospirillum Isolates on Maize cv. GM-3. Journal of Agricultural Science and Food Research, 7(1), 1-6. https://doi.org/10.4172/24712728.1000164

Kumar, M., Singh, D. P., Prabha, R., Rai, A. K., \& Sharma, L. (2016). Role of microbial inoculants in nutrient use 
efficiency. In Microbial Inoculants in Sustainable Agricultural Productivity (pp. 133-142). Springer.

Kurniawan, W. (2016). Kajian Pemberian Bakteri Endofitik terhadap Pertumbuhan dan Hasil pada Beberapa Varietas Tanaman Jagung (Zea mays L.) University of Muhammadiyah Malang].

Li, S., Nadolnyak, D., \& Hartarska, V. (2019). Agricultural land conversion: Impacts of economic and natural risk factors in a coastal area. Land Use Policy, 80, 380-390. https://doi.org/https://doi.org/10.1016/j.landusepol. 2018.10.016

Lin, Y., Watts, D. B., Kloepper, J. W., \& Torbert, H. A. (2018). Influence of Plant Growth-Promoting Rhizobacteria on Corn Growth Under Different Fertility Sources. Communications in Soil Science and Plant Analysis, 49(10), 1239-1255. https://doi.org/10.1080/00103624.2018.1457155

Malusà, E., Pinzari, F., \& Canfora, L. (2016). Efficacy of biofertilizers: challenges to improve crop production. In Microbial inoculants in sustainable agricultural productivity (pp. 17-40). Springer. https://doi.org/10.1007/978-81-322-2644-4

Maryamah, U., Sutjahjo, S. H., \& Nindita, A. (2017). Evaluasi Penampilan Sifat Hortikultura dan Potensi Hasil pada Jagung Manis dan Jagung Ketan. Buletin Agrohorti, 5(1), 88-97. https://journal.ipb.ac.id/index.php/bulagron/article/v iew/15896

Mcdonald, G., \& Meylinah, S. (2019). Indonesia Grain and Feed Annual Report 2019. http://www.usdaindonesia.org/indonesia-grain-andfeed-annual-report-2019/

Mehta, C., Emmanuel, B., Kesarwani, A., Sirari, K., \& Sharma, A. K. (2016). Nutrient management strategies based on microbial functions. In Microbial inoculants in sustainable agricultural productivity (pp. 143-163). Springer.

Moretti, L. G., Crusciol, C. A. C., Bossolani, J. W., Momesso, L., Garcia, A., Kuramae, E. E., \& Hungria, M. (2020). Bacterial Consortium and Microbial Metabolites Increase Grain Quality and Soybean Yield. Journal of Soil Science and Plant Nutrition, 20(4), 1923-1934. https://doi.org/10.1007/s42729-020-00263-5

Nezarat, S., \& Gholami, A. (2009). Screening plant growth promoting rhizobacteria for improving seed germination, seedling growth and yield of maize. Pakistan journal of biological sciences, 12(1), 26. https://doi.org/10.3923/pjbs.2009.26.32

Olanrewaju, O. S., \& Babalola, O. O. (2019). Bacterial Consortium for Improved Maize (Zea mays L.) Production. Microorganisms, 7(11), 519. https://www.mdpi.com/2076-2607/7/11/519

Panikkai, S., Nurmalina, R., Mulatsih, S., \& Purwati, H. (2017). Analisis Ketersediaan Jagung Nasional Menuju Swasembada dengan Pendekatan Model Dinamik. Informatika Pertanian, 26(1), 41-48. https://doi.org/10.21082/ip.v26n1.2017.p41-48

Pérez-Montaño, F., Alías-Villegas, C., Bellogín, R. A., del Cerro, P., Espuny, M. R., Jiménez-Guerrero, I., López-Baena,
F. J., Ollero, F. J., \& Cubo, T. (2014). Plant growth promotion in cereal and leguminous agricultural important plants: From microorganism capacities to crop production. Microbiological Research, 169(5), 325-336.

https://doi.org/https://doi.org/10.1016/j.micres.201 3.09.011

Pesireron, M., \& Senewe, R. E. (2011). Keragaan 10 Galur/Varietas Jagung Komposit dan Hibrida pada Agroekosistem Lahan Kering di Maluku. Budidaya Pertanian, 7(2), 53-59. https://ejournal.unpatti.ac.id/ppr_iteminfo_Ink.php?i $d=32$

Prasetyo, R. A., Soetopo, L., \& Sugiharto, A. N. (2018). Uji Daya Hasil 12 Calon Varietas Jagung Hibrida. Jurnal Produksi Tanaman, 6(9), 2354-2362.

Purwanto, Agustono, T., Widjonarko, B. R., \& Widiatmoko, T. (2019). Indol Acetic Acid Production of Indigenous Plant Growth Promotion Rhizobacteria from Paddy Soil [PGPR; rice; germination; IAA; vigor index.]. 2019, 7(1), 7. https://doi.org/10.18196/pt.2019.087.1-7

Richard, P. O., Adekanmbi, A. O., \& Ogunjobi, A. A. (2018). Screening of bacteria isolated from the rhizosphere of maize plant (Zea mays L.) for ammonia production and nitrogen fixation. African Journal of Microbiology Research, 12(34), 829-834. https://doi.org/10.5897/AJMR2018.8957

Santos, M. S., Nogueira, M. A., \& Hungria, M. (2019). Microbial inoculants: reviewing the past, discussing the present and previewing an outstanding future for the use of beneficial bacteria in agriculture. $A M B$ Express, 9(1), 205. https://doi.org/10.1186/s13568019-0932-0

Shah, P., \& Freedman, E. G. (2011). Bar and Line Graph Comprehension: An Interaction of Top-Down and Bottom-Up Processes. Topics in Cognitive Science, $3(3)$, 560-578. https://doi.org/https://doi.org/10.1111/j.17568765.2009.01066.x

Sirari, K., Kashyap, L., \& Mehta, C. (2016). Stress management practices in plants by microbes. In Microbial Inoculants in Sustainable Agricultural Productivity (pp. 85-99). Springer.

Sondang, Y., Anty, K., \& Siregar, R. (2019). Identification of endophytic and rhizosphere bacteria in maize (Zea mays L.) in Limapuluh Kota Region, West Sumatra, Indonesia. IOP Conference Series: Earth and Environmental Science,

Tchakounté, G. V. T., Berger, B., Patz, S., Fankem, H., \& Ruppel, S. (2018). Community structure and plant growth-promoting potential of cultivable bacteria isolated from Cameroon soil. Microbiological Research, 214, 47-59. https://doi.org/https://doi.org/10.1016/j.micres.201 8.05.008

Ullah, N., Ditta, A., Khalid, A., Mehmood, S., Rizwan, M. S., Ashraf, M., Mubeen, F., Imtiaz, M., \& Iqbal, M. M. (2020). Integrated Effect of Algal Biochar and Plant Growth Promoting Rhizobacteria on Physiology and 
Growth of Maize Under Deficit Irrigations. Journal of Soil Science and Plant Nutrition, 20(2), 346-356. https://doi.org/10.1007/s42729-019-00112-0

Velten, S., Leventon, J., Jager, N., \& Newig, J. (2015). What Is Sustainable Agriculture? A Systematic Review. Sustainability, 7(6), 7833-7865. https://www.mdpi.com/2071-1050/7/6/7833

Wen, X.-y., Dubinsky, E., Wu, Y., Yu, R., \& Chen, F. (2016). Wheat, maize and sunflower cropping systems selectively influence bacteria community structure and diversity in their and succeeding crop's rhizosphere. Journal of Integrative Agriculture, 15(8), 1892-1902.

https://doi.org/https://doi.org/10.1016/S20953119(15)61147-9

Youseif, S. H. (2018). Genetic diversity of plant growth promoting rhizobacteria and their effects on the growth of maize plants under greenhouse conditions. Annals of Agricultural Sciences, 63(1), 25-35. https://doi.org/https://doi.org/10.1016/j.aoas.2018.0 4.002

Zayed, M. S. (2016). Advances in formulation development technologies. In Microbial Inoculants in Sustainable Agricultural Productivity (pp. 219-237). Springer.

Zulfahmi, R., Bangun, M. K., \& Rosmayati, R. (2013). Respons Pertumbuhan Dan Produksi Tanaman Jagung (Zea Mays L.) Varietas Nonhibrida Dan Hibrida Terhadap Pemberian Bokashi Dan Pupuk Kalium. Jurnal Agroekoteknologi Universitas Sumatera Utara, 1(3), 95181.

https://jurnal.usu.ac.id/index.php/agroekoteknologi/ article/view/2936 